\title{
THE EFFECTIVENESS OF STRIPE RUST RESISTANCE GENE YR18 IN WHEAT CULTIVARS
}

\author{
S.L.H. VILJANEN-ROLLINSON and M.G. CROMEY
}

\author{
New Zealand Institute for Crop \& Food Research Ltd, Private Bag 4704, \\ Christchurch, New Zealand
}

\begin{abstract}
The wheat gene $\mathrm{Yr} 18$ conditions adult plant resistance to stripe rust (Puccinia striiformis) of wheat. Two field experiments in the 1996/97 growing season, and one experiment in 1997/98, were carried out to determine the effectiveness of this gene by comparing a range of cultivars with or without $Y r 18$. The cultivars were ranked in order of the value of area under disease progress curves (AUDPC). Cultivars possessing $\mathrm{Yr} 18$ had lower AUDPCs than those without the gene, but substantial disease epidemics occurred under heavy inoculum, suggesting $\operatorname{Yr} 18$ should not be used in isolation in disease control strategies based on disease resistance.
\end{abstract}

Keywords: durable resistance, Triticum aestivum, Puccinia striiformis.

\section{INTRODUCTION}

Stripe rust (caused by Puccinia striiformis Westend. f. sp. tritici) is a serious disease of wheat in many parts of the world, and has been the most significant wheat disease in New Zealand since the early 1980s. Severe infections of stripe rust can cause yield losses of up to $60 \%$ in susceptible cultivars (Beresford 1982). The disease can be controlled with fungicides or by seedling and adult-plant disease resistance. Seedling resistance is expressed at all stages of plant growth and is generally racespecific. Resistance is usually based on single major genes, and hence is relatively easy to transfer during plant breeding operations. In many cases, new pathotypes with virulence to these genes have developed rapidly after the introduction of cultivars possessing them rendering the resistance ineffective. Adult plant resistance develops progressively at later growth stages, is often quantitative (i.e. partial), and is based on single to many genes. Durable resistance remains effective in cultivars grown over wide areas in environments favourable to disease over long periods of time (Johnson 1992). Durable stripe rust resistance has been of the adult-plant resistance type.

Eighteen genes for resistance to stripe rust have been identified and several others have temporary designations (McIntosh et al. 1995). The genes $\operatorname{Yrl}, \operatorname{Yr} 6, \operatorname{Yr} 7, \operatorname{Yr} 9$, Yrl4 and $Y r A$ are common in wheat cultivars grown in New Zealand, but all of them are now less effective because of the occurrence of pathotypes that overcome their effects (Cromey and Munro 1992). Gene $Y r 18$ is an adult-plant resistance gene that has been reported to condition durable resistance (Ma and Singh 1996). Because it is a single gene, it has the advantage of ease of transfer in breeding programmes. The New Zealand cultivar, Karamu, contains the genes $\mathrm{Yr} 18$ and $\mathrm{YrA}$ and was, until recently, highly resistant to stripe rust in New Zealand. Since the detection of virulence to YrA in New Zealand in 1995, much of this resistance has been eroded (Cromey unpublished data). The experiments reported here were designed to determine the effectiveness in New Zealand of the resistance gene $\mathrm{Yr} 18$ in several cultivars of wheat. The presence of the gene $\mathrm{YrA}$ also needs to be considered because it may mask the expression of resistance of the gene $\mathrm{Yr} 18$. The effectiveness of the gene $\mathrm{Yr} 18$ must be determined before stripe rust control strategies using adult plant disease resistance can be developed. 


\section{6/97 experiments}

\section{METHODS}

Two autumn-sown field experiments separated by approximately $100 \mathrm{~m}$ were established at Lincoln, Canterbury, New Zealand. Each experiment had 16 cultivars in single $1 \mathrm{~m}$ long rows, separated by spreader rows of cultivar Oroua (susceptible to stripe rust pathotype 106E139A-) or Karamu (susceptible to pathotype 106E139A+), replicated four times. The rows were sown in blocks of six, with the spreader in the outer two rows and the middle two rows, with test lines in rows two and five. Plants of cv. Tiritea were sown in $10 \mathrm{~cm}$ pots, grown in a glasshouse and inoculated (Cromey 1992) either 15 days later with pathotype 106E139A- ( $Y r A$ avirulent, A- trial) or 16 days later with pathotype $106 \mathrm{E} 139 \mathrm{~A}+($ YrA virulent, A+ trial) isolated from cv. Karamu. Both pathotypes used were virulent on the genes $Y r 2$ and $Y r 7$, which were present in some of the test cultivars. The profusely sporulating inoculated plants were planted randomly amongst the spreader rows 14 or 15 days after inoculation when the plants at the experimental site had two emerged leaves. These plants remained in the experimental plots for the duration of the experiment. Disease was first noted in treatment plots on 10 October when plants at the experimental plots had five leaves unfolded, a main shoot and one or two tillers. Disease severity (\% leaf area infected) and infection type (IT) were scored on six occasions, each cultivar being given a whole plot score. The final infection types were:

- $\mathrm{R}=$ resistant, no visible infection or some chlorosis or necrosis, no uredia;

- $\mathrm{MR}=$ moderately resistant, small uredia present and surrounded by either chlorotic or necrotic areas;

- MS = moderately susceptible, medium-sized uredia present and possibly surrounded by chlorotic areas;

- $\mathrm{S}=$ susceptible, large uredia present, generally with little or no chlorosis and no necrosis.

The area under the disease progress curve (AUDPC) was calculated for each cultivar over time using the formula

$$
\text { AUDPC }=\sum_{i=1}^{n} 1 / 2\left(Y_{i}+Y_{i-1}\right)\left(X_{i}-X_{i-1}\right)
$$

where $\mathrm{Y}_{i}=$ rust severity at the $i$ th observation, $\mathrm{X}_{i}=$ time (d) at the $i$ th observation, $\mathrm{n}$ $=$ total number of observations, and $Y_{0}=X_{0}=0$. Values of AUDPC of each cultivar were subjected to analysis of variance.

\section{7/98 experiment}

A spring-sown field trial containing 10 cultivars and four replicates was established at Lincoln. Cultivars included near isogenic (genetically similar) lines with and without the gene $\operatorname{Yr} 18$, as well as other cultivars (susceptible or durably resistant; Table 2). Plots were $3.5 \mathrm{~m}$ long, and consisted of two sub-plots (six rows each), separated by $0.5 \mathrm{~m}$. Two spreader rows (a mixture of cultivars Oroua and Karamu) were located at east and west sides of the trial. Fungicide (tebuconzale at $189 \mathrm{~g} / \mathrm{ha}$ ) was applied at approximately 3-week intervals to one set of sub-plots in each replicate as a nil disease treatment. Stripe rust was allowed to develop in the remaining plots, relying on natural inoculum.

Disease severity and infection type were assessed on flag leaves on 11 occasions from 12 November 1997 until 12 January 1998. AUDPCs were calculated for the flag leaves of the nil-fungicide treatment plots as described above. Plots were harvested at crop maturity and grain weights were recorded. Values for AUDPC and yield $/ \mathrm{m}^{2}$ were analysed by analysis of variance.

\section{6/97 experiments}

\section{RESULTS}

To ascertain the effect of the gene $\mathrm{Yr} 18$, the presence or absence of the gene $\mathrm{YrA}$ needs to be considered. There was less disease overall (ignoring cultivars with the gene $\operatorname{YrA}$ ) in the A+trial than in the A-trial, suggesting that A-trial was more conducive to the development of stripe rust (Table 1). AUDPC values were different $(\mathrm{P}<0.001)$ between cultivars, and there was a significant $(\mathrm{P}<0.001)$ race by cultivar interaction. 
The effect of the gene $\operatorname{Yr} 18$ can be seen in the A- trial by comparing cultivars which have the gene $\operatorname{Yr} 18$ but not the gene $\operatorname{YrA}$, while in the A+trial, presence of the gene $Y r A$ can be ignored due to the use of a $Y r A$ virulent pathotype. In the A-trial the AUDPC of cultivar Thatcher was 2849 but only approximately 780 in Thatcher cultivars containing the gene $\mathrm{Yr} 18$. Likewise, the AUDPC value of Jupateco S was greater than the two Jupateco R cultivars. AUDPCs for all lines with gene $\mathrm{Yr} 18$ were approximately half those of lines with resistance genes, or resistance genes matched by corresponding virulence, except for Oroua and Endeavour. Cultivars containing the gene $\operatorname{YrA}$ (Karamu, Anza, Avocet R, WW15R and WW15S) had greater AUDPCs and greater maximum disease severities in the A+trial than A-trial. This indicates that there was limited mixing of pathotypes in the two trials, at least in the early stages. Avocet $\mathrm{R}$ was the most diseased line in the A+ trial with AUDPC almost twice that of the next most susceptible cultivar, Thatcher. The maximum disease severity of Avocet $\mathrm{R}$ was $100 \%$ in the A+trial, but only $88 \%$ in the A-trial. Final infection types ranged from susceptible in cultivars such as Avocet, Kalyonsona and Thatcher, to moderately resistant in cultivars such as Karamu and Anza where virulence to $\mathrm{YrA}$ was uncommon.

TABLE 1: Area under disease progress curves (AUDPC), maximum mean disease severity (DS, percentage of leaf area infected) and final infection type (IT) on cultivars of wheat (with relevant resistance genes in brackets) in the 1996/97 field experiments, inoculated with two pathotypes of Puccinia striiformis.

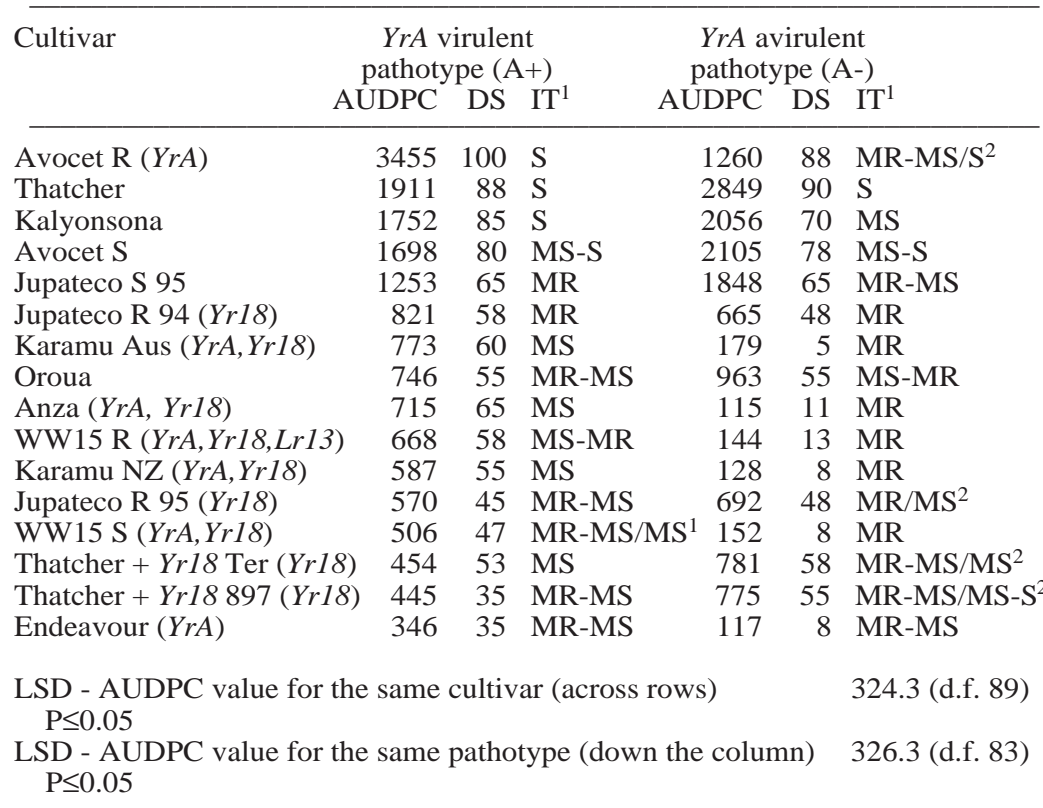

${ }^{1}$ Infection type: $\mathrm{R}=$ resistant; $\mathrm{MR}=$ moderately resistant; $\mathrm{MS}=$ moderately susceptible and $\mathrm{S}=$ susceptible.

${ }^{2}$ The different infection types for this cultivar refer to another pathotype infecting this cultivar late in the season.

\section{7/98 experiment}

The AUDPC values were different $(\mathrm{P}<0.001)$ between cultivars (Table 2). Amongst cultivars containing the gene $\operatorname{Yr} 18$, AUDPC value was greatest for Jupateco R and then 
for Thatcher 897. AUDPC was not different between Jupateco R containing the gene Yrl8 and the susceptible cultivar, Rongotea. Thatcher was the most susceptible cultivar, with the greatest AUDPC value and greatest severity (94\%). The AUDPC values in the related cultivars Karamu, Anza and in both WW15 lines were similar to each other, and to the AUDPC value for Otane. The reduction in AUDPC value was greater in Thatcher than Jupateco when comparing lines with and without the gene Yr18. Final infection types (Table 2) were susceptible in Thatcher and Jupateco S, but moderately susceptible to moderately resistant in all the other cultivars. The cultivars yielded more $(\mathrm{P}=0.012)$ in plots sprayed with fungicide than in untreated plots $\left(0.147 \mathrm{vs} 0.136 \mathrm{~kg} / \mathrm{m}^{2}\right.$ respectively) but no significant cultivar by fungicide interaction $(\mathrm{P}=0.539)$ was detected.

TABLE 2: Area under disease progress curves (AUDPC), maximum mean disease severity (DS, percentage of leaf area infected), final infection type (IT) on flag leaves in unsprayed plots, and yield for cultivars of wheat in the 1997/98 field experiment relying on natural inoculum of Puccinia striiformis.

\begin{tabular}{lrrlcc}
\hline Cultivar & AUDPC & DS & IT $^{1}$ & \multicolumn{2}{c}{ Yield $\left(\mathrm{kg} / \mathrm{m}^{2}\right)$} \\
& & & & No fungicide & Fungicide \\
\hline Thatcher & 1620 & 94 & S & 0.420 & 0.483 \\
Jupateco S 95 & 1050 & 60 & S & $0.077^{2}$ & $0.101^{2}$ \\
Jupateco R 95 & 685 & 38 & MS-MR & $0.095^{2}$ & $0.105^{2}$ \\
Rongotea $^{3}$ & 544 & 35 & MS & 0.558 & 0.614 \\
Thatcher + Yr18 897 $^{3}$ & 329 & 38 & MS-MR & 0.424 & 0.439 \\
Otane $^{3}$ & 160 & 10 & MR-MS & 0.329 & 0.350 \\
WW15 R & 156 & 14 & MR-MS & 0.227 & 0.301 \\
Karamu & 134 & 15 & MS-MR & 0.385 & 0.394 \\
WW15 S & 126 & 11 & MR-MS & 0.323 & 0.348 \\
Anza & 81 & 11 & MS-MR & 0.324 & 0.364
\end{tabular}

LSD - AUDPC value $\mathrm{P} \leq 0.05$

$262.4(26 \mathrm{df})$

LSD - yield of same cultivar with different levels of fungicide (across rows) $\mathrm{P} \leq 0.05$

LSD - yield of different cultivars with same levels of fungicide (down the column) $\mathrm{P} \leq 0.05$

${ }^{1}$ Infection type: $\mathrm{R}=$ resistant; $\mathrm{MR}=$ moderately resistant; $\mathrm{MS}=$ moderately susceptible and $\mathrm{S}=$ susceptible.

${ }^{2}$ Bird damage in this cultivar.

${ }^{3}$ No identified resistance genes.

\section{DISCUSSION}

In the 1996/97 experiments, lines containing the gene $\operatorname{Yr} 18$ had less disease as measured by the AUDPC than those with no effective disease resistance genes for stripe rust. In the $\mathrm{A}+\operatorname{trial}$ (where the gene $Y r A$ is not effective), the presence of the gene Yrl 8 reduced the AUDPC by up to $77 \%$ and maximum disease severity from 88 to $35 \%$ (Thatcher lines). Overall, there was less disease in the A+trial than in the A-trial, when the effect of $Y r A$ is ignored (i.e. in cultivars without the gene $Y r A$ ). This meant that the A- trial was more conducive to the development of stripe rust than the A+trial, probably because the greater susceptibility of Oroua to pathotype 106E139A- than Karamu to pathotype 106E139A+ resulted in more inoculum potential in the A- trial than in the A+ trial.

The two stripe rust pathotypes were successfully separated, at least during the early part of the epidemics, as shown by significant race by cultivar interactions. Some mixing of pathotypes, and possibly the arrival of further ones, occurred later in the season. This was demonstrated by changes in infection types to moderately susceptible 
or susceptible in WW15 S in the Karamu trial as well as changes in the infection types in Thatcher lines containing $\mathrm{Yr} 18$ and in the Jupateco R 94 line in the Oroua trial (Table 1, footnote 2). Avocet $\mathrm{R}$ was more susceptible than Avocet $\mathrm{S}$ in the presence of $\mathrm{YrA}$ virulence, with greater final maximum disease severity, indicating that these two reselections from Avocet differ in background resistance to stripe rust as well as in the presence or absence of $\mathrm{YrA}$.

The results of the 1997/98 experiment again showed that the Thatcher background is very highly susceptible to stripe rust: in the presence and absence of the gene $\mathrm{Yr} 18$, there was a greater reduction in the AUDPC in the Thatcher line than in the Jupateco line. Jupateco with $\operatorname{Yr} 18$ proved no more resistant than the susceptible Rongotea. Stripe rust did not establish in the experimental plots until early December resulting in a shorter, less severe epidemic than if inoculum had been available earlier. Nevertheless, the differences between the lines containing the gene $\operatorname{Yr} 18$ and those without this gene indicated that relying solely on the gene $\operatorname{Yr} 18$ does not confer adequate resistance to stripe rust, and a degree of background resistance is required. It should be possible to increase the level of resistance by combining a few additive adult plant resistance genes in a breeding programme (Johnson 1992; Ma and Singh 1997). The selection process would be aided by identifying components of resistance, such as latent period, infection frequency, lesion length and growth rate (Broers 1997).

The stripe rust reactions in Karamu, Anza, WW15 lines (all related) and Otane were similar. Otane is considered to have durable resistance to stripe rust as it has been grown widely for a number of years in New Zealand and has consistently exhibited a moderate level of adult plant resistance (Cromey 1992). Further studies are needed to determine the genetic basis of resistance in Otane and, in particular, determine whether it also contains $\operatorname{Yr} 18$.

Stripe rust developed in experimental plots in 1997/98 relatively late in the season. Hence, yield effects of disease were slight. In addition, both lines of Jupateco were very early maturing and badly damaged by birds, which possibly masked yield differences. Further studies are underway to ascertain the effects of $\operatorname{Yr} 18$ on the development of stripe rust epidemics and on yield.

This research has shown that there is potential to improve the durability of stripe rust resistance in New Zealand wheat cultivars and the level of this resistance by incorporating the gene $\mathrm{Yr} 18$ in new cultivars, along with good background resistance.

\section{ACKNOWLEDGEMENTS}

This research was funded by the NZ Foundation for Research, Science and Technology. Helen Boddington gave technical assistance, Cathy Munro managed the trials and Ruth Butler assisted with statistical analysis of the data.

\section{REFERENCES}

Beresford, R.M., 1982. Stripe rust (Puccinia striiformis), a new disease of wheat in New Zealand. Cereal Rusts Bull. 10: 35-41.

Broers, L.H.M., 1997. Components of quantitative resistance to yellow rust in ten spring bread wheat cultivars and their relations with yield assessments. Euphytica 96: 215-223.

Cromey, M.G., 1992. Adult plant resistance to stripe rust (Puccinia striiformis) in some New Zealand wheat cultivars. N.Z. J. Crop Hort. Sci. 20: 413-419.

Cromey, M.G. and Munro, C.A., 1992. Stripe rust resistance in New Zealand wheat cultivars. Vort. für Pflanzenzücht. 24: 276-278.

Johnson, R., 1992. Past, present and future opportunities in breeding for disease resistance, with examples from wheat. Euphytica 63: 3-22.

Ma, H. and Singh, R.P., 1996. Contribution of adult plant resistance gene $\operatorname{Yr} 18$ in protecting wheat from yellow rust. Plant Dis. 80: 66-69.

Ma, H. and Singh, R.P., 1997. Resistance to stripe rust in five durum wheat cultivars. Plant Dis. 81: 27-30.

McIntosh, R.A., Wellings, C.R. and Park, R.F., 1995. Wheat Rusts: an Atlas of Resistance Genes, CSIRO, Australia. 200 pp. 